\title{
México and the TPP: a critical view on diversification and intellectual property
}

Juan Felipe López Aymes*

\author{
*Correspondence: \\ jflopezaymes@hotmail.com \\ Centro Regional \\ de Investigaciones \\ Multidisciplinarias, UNAM, Av. \\ Universidad s/n, Circuito 2, \\ 62210 Cuernavaca, Morelos, \\ Mexico
}

\begin{abstract}
The Trans Pacific Partnership Agreement was signed on February 4, 2016. The published text confirmed some fears but also brought relief as the details of what had been negotiated became publicly known. This paper attempts to contribute to the discussion with a critical view of the Agreement, although not necessarily in equivalence to US President-elect Donald Trump negative stand, but one of a developing country. The main argument holds that joining the TPP, or any other agreement alike, is not advisable unless Mexican industries are in a condition to compete. The line of reasoning is double-faceted: First, gains from the alleged diversification are insignifcant, so handing over policy autonomy for development in exchange for access to negligible markets is not beneficial; second, its strong intellectual property rules would further hinder the policy space of the government for designing and implementing domestic science, technology and innovation programs. This would place Mexico at a disadvantage with regard to its prospects for a higher position in global production and value chains, not to mention develop full production chains led by national firms. As it is presently formulated, the Trans Pacific Partnership Agreement would consolidate a structure of dependence and income inequality, two problems which Mexico is striving to overcome.
\end{abstract}

Keywords: Trans Pacific Partnership, TPP, Mexico, Diversification, Intellectual property rights

\section{Background}

The full Trans Pacific Partnership Agreement (TPP) document was released one month after the announcement of its conclusion on October 5,2015 . The published text confirmed some fears ${ }^{1}$ but also brought relief as the details of what had been negotiated by twelve very diverse countries on the Pacific Rim became known. ${ }^{2}$ The text has being analyzed by legislative bodies, their constituencies, stakeholders and civil society organizations to assess the convenience of joining the partnership and to address possible challenges in its implementation, including recent announcement by President-elect Donald Trump that the US would withdraw from the TPP. Since the text can no longer be modified, the only option at this point is whether or not to join. Nevertheless, such a decision is difficult because, as to be expected, parts of the agreement are favorable while others are not. The TPP has been labeled as one of the most relevant contemporary trade mechanisms, not only because of the economic

\footnotetext{
${ }^{1}$ See Public Citizen website: http://www.citizen.org/TPP. Accessed April 14. 2016.

2 The signatory countries are Australia, Brunei, Canada, Chile, Japan, Malaysia, Mexico, New Zealand, Peru, United States, Singapore and Vietnam.
}

(c) The Author(s) 2017. This article is distributed under the terms of the Creative Commons Attribution 4.0 International License (http://creativecommons.org/licenses/by/4.0/), which permits unrestricted use, distribution, and reproduction in any medium, provided you give appropriate credit to the original author(s) and the source, provide a link to the Creative Commons license, and indicate if changes were made. 
weight of some of its members, but also because it addresses a sweeping range of issues including trade liberalization, an ambitious coverage of products and services, and rules governing non-trade-related matters such as investment and intellectual property rights (IPRs) (Barfield 2011). It has also stirred controversy over the limited and biased scope of the domestic economic policy options it allows participants and because it would set a new institutional framework for interaction between national governments and transnational corporations (TNCs)—one that is clearly slanted for the latter (Kolsky Lewis 2011; Rochon 2013). ${ }^{3}$

This article contributes to the TPP debate with a critical stance on its implications for Mexican economic diversification goals and on the likely consequences of its IPR chapter. The analysis here contests its alleged long-term benefits for the public interest and wellbeing. I engage in the debate with the intention of showing the marginal impact that trade agreements have historically exerted on diversification, and to challenge the convenience for adopting strong IPR regimes in developing countries. My critique of the TPP dovetails with the argument that bringing economic benefits to the general public and the opportunity for Mexican firms-not only TNCs in Mexico-to engage in top tier, high-tech and high-value activities within global production chains, or develop full production chains domestically does require implementing a targeted developmental economic policy before joining. Upgrading the technological status of the Mexican industrial base poses a domestic challenge, and strict IPR regimes-especially with regard to patent regulations-are likely to hinder rather than stimulate local development, as occurred with the pharmaceutical industry in the 1990s. ${ }^{4}$

I question the benefits of joining the TPP on the following grounds: First, previous experiences with trade agreements and the current structure of trade relations clearly demonstrate that the possibilities of economic diversification are insignificant. Handing over policy autonomy in many other crucial areas (such as foreign investment regulations and support to technology development) in exchange for access to negligible markets is an ill-advised bargain (Shadlen 2005). Second, the TPP rules on IPRs-even stricter than those of the World Trade Organization (WTO)-limit the policy space of governments for pursuing development goals, inter alia, cultivating the technological capabilities of the national economy and enhancing knowledge-based skills and innovation. Should the TPP be ratified, the prospects for achieving a stronger Mexican industry in global production/value chains and for nurturing infant industry are remote. As a consequence, the TPP would consolidate a structure that promotes instead of eliminating dependency and income inequality as benefits are concentrated in TNCs.

\section{Methods}

It can be safely concluded that the TPP would hardly contribute to the two avowed policy objectives of diversifying economic relations and improving the knowledge governance system in the service of national development goals. With this in mind, I structured

\footnotetext{
${ }^{3}$ From the Public Citizen website, see "The Trans-Pacific Partnership: Empowering Corporations to Attack Nations" (http://www.citizen.org/Page.aspx?pid=5411). Accessed April 14, 2016.

${ }^{4}$ As a condition to negotiate the North America Free Trade Agreement (NAFTA), Mexico agreed to comply with the rules of the Trade-Related Aspects of Intellectual Property Rights (TRIPs) in 1991, while such regime was still under negotiation-that is, not immediately before the TRIPs came into effect in 1995, but much earlier than the date stipulated for developing countries (2006) — unilaterally overlooking most of the flexibilities provided. Moreover, Mexico renounced to its former IPR regime and retroactively recognized pharmaceutical and other patents, which according to Mexican law were not patentable. As a result, Mexican pharmaceutical firms were driven to extinction or forced down the value chain to become producers of generics and incremental innovators, thereby its diminishing R\&D and innovation capabilities (Aboites and Soria 2008).
} 
this research with a twofold objective: to evaluate progress made by Mexico in de-concentrating its economic relations by opening new markets through formal agreements, and to consider the impact of stronger IPR protection on achieving a more autonomous path to economic development. I approached these aspects of the TPP by formulating two research questions. First, in relation to the pro-TPP stance adopted by the Mexican government on the assumption that it provides vast opportunities to enter new markets in Asia, I ask: Based on Mexico's experience with bilateral and multilateral trade agreements, is it realistic to expect economic diversification as a consequence of the TPP? If the answer to this question is no, we would then ask: Are institutional changes to accommodate the TPP justifiable? Second: How would the TPP chapter on IPR affect the nation's ability to design and implement programs for developing domestic science, technology and innovation capabilities? Evidence on both issues was obtained through a simple data search regarding the trade relations that Mexico has sustained with TPP members as export markets. I focused on the relative de-concentration achieved by Mexico vis-à-vis the United States (US) and on the export diversification potential claimed by the Mexican government. Other aspects of trade diversification such as foreign direct investment (FDI) were also taken into account. With regard to IPR impact specifically, I conducted a qualitative analysis of the ongoing debate on the implications of strong IPR regulations for industrial policy and economic development. I drew the data primarily from a literature search of secondary sources and from direct references to the TPP text.

The limited scope of this article does not allow for covering the totality of TPP chapters. Therefore I centered the analysis on Chapter 18 regarding Intellectual Property, specifically on its patent-related Sections F and G and their subsections. The decision was prompted by evidence suggesting that strong IPR regulations ${ }^{5}$ such as those proposed by the TPP not only stifle innovation, but actually limit the production and accumulation of new knowledge. Evidence relates primarily to the global IPR regime launched in the 1980s and embodied in the WTO-TRIPS, free trade agreements and bilateral investment agreements. As a result, the domestic industries of developing countries are left to pursue only incremental and low-value innovation (Aboites et al. 2011; Aboites and Soria 2008). Moreover, strong IPR regulations render the use and transfer of technology more expensive for developing countries, encourage strategic patenting abuse on the part of large firms (Ernst 2015b), and force signatory members to adhere to other agreements that may also prove detrimental to local producers seeking to develop their technological capacities. ${ }^{6}$ Open access and use of technology is deemed a fundamental condition for establishing higher-value domestic firms capable of either generating economic spillovers or penetrating current global production chains in the

\footnotetext{
${ }^{5}$ Strong intellectual property regimes are those that protect owners and producers of knowledge and inventions by excluding others from the exploitation of such assets, while weak regimes are those that encourage the widespread use of knowledge-assets, resulting from research and development investments undertaken by firms and individuals (Ordover 1991: 43).

${ }^{6}$ For instance, according to TPP's Article 18.7: International Agreement members are obliged to eventually join, among others, the Patent Cooperation Treaty, as amended September 28, 1979; the Paris Convention, as revised in Stockholm, July 14, 1967; the Budapest Treaty, as amended on September 26, 1980, which requires that all parties recognize microorganisms deposited as a part of the patent procedure, regardless of where the depository authority is located; the International Union for the Protection of New Varieties of Plants or UPOV, as revised at Geneva, March 19, 1991, which protects new varieties of plants as intellectual property rights, and of course, accept the TRIPs Agreement and its respective amendments.
} 
higher tiers. International agreements which compromise access to technology should not be the price of assuring the long-term prospects of economic development and wellbeing of countries in the South (Olwan 2013). Such concessions constitute the underlying argument of the present article. While strong IPR regimes may be adequate for knowledge governance among advanced techno-dependent economies, more flexible protection is required to stimulate knowledge diffusion and to support more effective national science and technology (S\&T) policies in less advanced countries.

Three caveats are in order: First, I acknowledge that even if patent rules are weak and access to knowledge is open, no significant and economically useful knowledge and innovation is achievable without high educational standards and appropriate S\&T policies (including financial support). Having said this, however, it is clear that strong IPR regulations make it difficult for firms in developing countries to take risks and invest in R\&D, even if public policies "encourage" them to do so. Second, Section J on Internet Service Providers is controversial with regard not only to human rights and criminalization in the use of the Internet, but also to its potential impact on economic development. Nonetheless, its discussion is beyond the scope of this article. Third, other sections of Chapter 18 such as Trademarks (C), Country Names (D), Geographic Indicators (E) and Copyrights $(\mathrm{H})$ are considered important and to some extent favorable for the public interest; I therefore do not take a strong stance on these regulatory measures.

\section{The road to TPP: How did we get here?}

As is well known, the TPP started as a somewhat more modest 10-year integration project among several small countries (Chile, Brunei, New Zealand, and Singapore) on three continents with insignificant trade relations. The first agreement was signed in 2005 and took effect in May 2006.

The agreement maintained a low profile until 2008, when the US announced its interest in joining; shortly thereafter, Australia, Peru, Vietnam and Malaysia followed suit. In 2009, Barack Obama committed to participating in the negotiation process, thereby placing the TPP on the region's radar (Barfield and Levy 2009). Since then, Washington has dictated the TPP agenda and has declared that it will set the "goal of shaping a regional agreement that will have broad-based membership and the high standards worthy of a twenty first century trade agreement." ${ }^{7}$ This triggered an interregional movement which would have been unlikely to occur otherwise. Not surprisingly, given the complexity and scope of the TPP goals, negotiations were lengthy and held mostly in secret, with frequently missed deadlines (Rochon 2013). In June 2015, Obama was granted Trade Promotion Authority to speed up the negotiations and provide some assurance of a commitment from the US. Until then, the TPP was relatively unknown in Mexico and passed almost unnoticed by national media.

By the time TPP negotiations kicked off, most economies were already comparatively open. Many had trade agreements in place and enjoyed favorable access to the US market. Therefore, trade itself appeared to be the least relevant issue as opposed to the stringent non-trade related issues.

\footnotetext{
7 "U.S. engagement with the Trans-Pacific Partnership: Action to date," USTR November 14, 2009. https://ustr.gov/ about-us/policy-offices/press-office/fact-sheets/2009/december/tpp-statements-and-actions-date. Accessed April 7, 2016.
} 
The TPP comprises 29 chapters, some of which deal with controversial and sensitive matters including competition rules for state enterprises and a mechanism for settling investor-state disputes (ISDS). ${ }^{8}$ It also contains provisions on IPRs, regulatory coherence, labor and environmental regulation, rules of origin, public sector procurement, e-commerce services and the Internet, financial services, telecommunications, and even accounting, transparency and corruption. It establishes rules for trade and investment relations, as well as for domestic public policy choices. Generally, FTAs affect public policies as do any formal agreements requiring parties to adjust their policies in order to reap the perceived gains from the new conditions. From this view, therefore, FTAs are meant to change domestic policies as they become common rules for reducing transaction costs. Given the wide scope of its items and areas of concern, the TPP imposes a standard of rules that obliges the parties to choose from a very limited set of options in areas well beyond trade and investment, regardless of their own policy preferences and development goals. Notwithstanding the time frame negotiated by each party for adjusting practices and institutions, the TPP ultimately aims to establish one criterion of wellbeing, freedom and development, as well as a fixed role for participants in the global value chains, without either consideration for their domestic needs and beliefs or an understanding of what is best for their local communities. This has clear political economy implications for the development of its members. They need to seriously consider two fundamental issues: how would the new rules affect their sovereignty and policy space (DiCaprio 2010; DiCaprio and Gallagher 2006; Gallagher 2007) ${ }^{9}$ as well as their opportunities for upgrading their position in the regional and global value/production chains versus locking into the lowvalue locus? Many fear that the changes would lead to the second scenario.

While the TPP contemplates preferential access for member countries, the majority of chapters contain regulations that protect the activities and interests of TNCs (Rochon 2013). That is not necessarily an evil thing in itself were it not coupled with disregard for development and social policies directed at making trade and investment fairer. The establishment of rules that level the playing field among actors with uneven levels of development does not seem right. Expecting transnational companies to share technology and favor wealth distribution measures is historically unfounded, unless mediated by development-driven intervention. Therefore, one of the most severe criticisms of the Agreement concerns its most probable outcome: It appears designed to predominantly benefit large corporations (instead of serving developing economies) by imposing restrictions that render infant industry and domestic technological progress difficult if not impossible. In other words, the TPP is not designed to facilitate trade, reduce international monopolies or limit the power of TNCs; it is steered towards defending the interests of big corporations and institutionally underpinning their control over domestic development options (Stiglitz and Hersh 2015). More emphatically than other signatories, the US government has insisted on rules of this nature in the WTO and bilateral trade agreements it has negotiated.

\footnotetext{
${ }_{8}^{8}$ The ISDS is the international system whereby transnational companies can sue the governments of countries in which they invest for affecting their business interests, expectations, or for violating their property rights. It grants an investor the right to use dispute settlement proceedings against a foreign government by using ad hoc extrajudicial tribunals that are authorized to order compensation.

${ }^{9}$ Both Gallagher and DiCaprio's papers refer to the WTO negotiations debate, which is similar to the discussions on TPP.
} 
For several decades, the General Agreement on Tariffs and Trade (GATT) and its heir, the WTO, have provided the multilateral negotiation and mediation mechanisms for trade (largely concerning import tariffs and market access). This has worked fairly well, given the characteristics of international production and capital mobility of the postwar era, distinguished by more centrally organized production chains and somewhat restrictive financial flows. However the evolution of the global productive and financial systems has brought new challenges and issues, such as IPR protection, which have indirectly affected the trade of goods and services. The Uruguay Round (1986-1994) attempted to tackle some of the emerging issues on the international trade agenda, but soon faced resistance leading to stalemate. The Asia Pacific Economic Cooperation (APEC) forum, created in 1989, resuscitated multilateral negotiations, and a Free Trade Agreement kicked off in 1992 as an outgrowth of the Association of South East Asian Nations (ASEAN). Shortly thereafter, in 1994, Canada, Mexico and the US launched an economic integration project culminating in the North America Free Trade Agreement (NAFTA).

Nevertheless, negotiations on new rules for international trade through multilateral mechanisms are stalled again. As occurred in the Uruguay Round, the current Doha Round is stagnant. Many countries are thus opting to move forward and establish their own regional or bilateral rules, with some members unwilling to add new partners (Baldwin et al. 2013; Drysdale 2013). The advent of mechanisms such as the TPP and its rival, the Regional Comprehensive Economic Partnership (RCEP), is an indication that, among other things, the timeworn rules of the international trade system have been unable to adapt to the growing importance of emerging economies (Aggarwal 2016). Instead, they mainly serve to accommodate the interests of large companies and new forms of international production such as business networks and modularization. Paradoxically, one of the most significant problems facing the TPP is the fact that the rules it proposes are precisely the ones that triggered the most resistance within the WTO, leaving the Doha Round at an impasse (Haunss 2013).

Throughout the last three or four decades, along with the institutional development of the postwar international trade regime, the Asia Pacific region has developed a regionalization process at the margins of the WTO. As part of this process, US exports have been gradually excluded from the Asian market. This is attributable not only to the intra-regional pacts initiating in the 1990s and proliferating in the 2000s (Bergsten and Schott 2010), but also to the Japanese, Korean, and Chinese business networks taking over the South East Asian economies. The exclusion of the US has been driven by Chinese eagerness to endorse a primarily Asian commercial and institutional structure (Bergsten 2007). Anxious to stay onboard, the US has sought to redefine its position in the Asian political economy alongside its longestablished role in the security realm (Limaye 2011; Solis 2011).

From the US perspective, the growing importance of Asia and the Pacific in the world economy means that the TPP could evolve into the long-desired Asia Pacific Free Trade Agreement yet serve as a precursor to a new set of regional and global rules with the US retaining a central role (Petri et al. 2011; Kolsky Lewis 2011). However, such a system faced great opposition in the US; its controversial provisions actually became one of the 
central issues in during 2016 presidential elections. ${ }^{10}$ Two weeks after electoral results were confirmed, the President-elect Donald Trump stated that in the first 100 days of his administration, he would "issue a notification of intent to withdraw from the Trans Pacific Partnership" and "negotiate fair bilateral trade deals".11 The Agreement is also under attack by civil society in other signatory countries ${ }^{12}$ and, significantly, by the RCEP, which has positioned itself as an alternative integration process, especially after Trump's statement. ${ }^{13}$ In fact, the latter has excluded the US from the rule-making process, and has adopted ASEAN as the central actor, although it is common knowledge that the partnership gravitates around China. ${ }^{14}$

Clearly, the TPP and the RCEP are tokens of the economic and political rivalry between the US and China, with both powers competing to establish the rules of the game for the new regional order. In this geopolitical context, the TPP can be seen as a manifestation of US economic diplomacy determined to form an institutional siege to contain China in the international system (Sakai 2011; de María y Campos 2016); the conspicuous absence of China is one of the most controversial characteristics of the TPP (Armstrong 2011). ${ }^{15}$ China has its own view of development and has played with the international trade and investment rules in a way that many observers qualify as predatory but conveniently serves its development purposes. Even though China is part of the WTO and thus constrained by its rules, it has nevertheless developed several industries from scratch using the widest margin of political discretion that WTO flexibilities allow and often ignoring international community admonitions to behave according to international expectations (He 2015). In particular, China has been rebuked for unfair practices flowing from the dominance of its state-owned enterprises in international trade and investment. In anticipation for an eventual Chinese admittance, several TPP chapters targeted such issues, for instance Chapter 9 on Investment, Chapter 15 on Government Procurement, Chapter 16 on Competition, and especially Chapter 17 on State-Owned Enterprises. IPR protection (Chapter 18 on Intellectual Property, specifically on the regulation of patents, trademarks, copyrights, and others) has surfaced among the top critical issues relating to China (Dimitrov 2009). Some industries dominated by TNCs have been antagonized by the strategies employed by China for attaining its development goals, inter alia, promoting infant industries in crowded markets (such

\footnotetext{
${ }^{10}$ ICTSD, “Tensions Run High on US Presidential Campaign Trail as TPP Debate Continues," Bridges Weekly, April 7, 2016. http://www.ictsd.org/bridges-news/bridges/issue-archive/tensions-run-high-on-us-presidential-campaign-trailas-tpp-debate. Accessed April 14, 2016.

11 “A Message from President-Elect Donald J. Trump", published on Youtube.com November 21, 2016. https://www.youtube.com/watch?v=7xX_KaStFT8\&feature=share. Accessed November 22, 2016.

12 See Macarena García Lorca, "Chile: Las críticas al TPP y la respuesta de la sociedad civil a Heraldo Muñoz", Bilaterals.org, February 12, 2016. http://www.bilaterals.org/?chile-las-criticas-al-tpp-y-la\&lang=en. Accessed April 14, 2016; "Declaraciones del 'Encuentro Internacional de Organizaciones Sociales en oposición al TPP”, Bilaterals.org, February 3 , 2016. http://www.bilaterals.org/?declaraciones-del-encuentro\&lang=en. Accessed April 14, 2016; and Sujata Dey, "The TPP Erodes Public Policy to Benefit the World's Plutocrats", Huffington Post, January 20, 2016. http://www.huffingtonpost.ca/sujata-dey/trans-pacific-partnership-plutocrats_b_9009838.html. Accessed April 14, 2016; and AFL-CIO, et al. “TPP Joint Letter to President Obama," submitted to The White House on December 16, 2014. http://www.aflcio.org/ content/download/146881/3760211/file/TPP-Joint+Letter+Dec+17+2014+FINAL.pdf. Accessed April 13, 2016.

13 Ami Miyazaki and Tom Westbrook “Trump sinks Asia trade pact, opening the way for China to lead" Reuters.com November 22, 2016. http://www.reuters.com/article/us-usa-trump-tpp-idUSKBN13H0OT. Accessed November 22, 2016.

14 The initiative of launching RCEP negotiations came up during the ASEAN leader's summit in November 2012.

15 See also: Jianmin Jin, “China's Concerns Regarding TPP no More than Empty Worries?” Fujitsu Research Institute, Current Topics, January 11, 2012. http://jp.fujitsu.com/group/fri/en/column/message/2012/2012-01-11.html. Accessed 13 April 2016.
} 
as the civil aircraft industry) by partially circumventing WTO rules (He 2015). The TPP clearly sought to regulate irritating Chinese trade practices and to forestall their replication as an RCEP model. It may also be aimed to counter the adoption of alternative international cooperation proposals under the BRICS, of which China is an influential partner. ${ }^{16}$ Although the BRICS members' are not currently engaged in discussing an alternative FTA, the new financial agencies created in 2014 may have indirect implications on interregional trade relations (Contipelli and Picciau 2015). ${ }^{17}$

In principle, the TPP promises as one of its primary attributes to coexist with other regional and sub-regional trade agreements including NAFTA. This means that the TPP regime would overlap with other RTA regulations such as rules of origin, ${ }^{18}$ exacerbating the complexity of the institutional maze already in place. It remains to be seen how the TPP would actually function in the event it receives final approval by the US Congress and the other signatory countries. It seems obvious that it would multiply the number of rules and standards, thus rendering transactions more complicated, and would erode privileges gained under other agreements. In fact, this is what the Mexican government holds as its main motivation for joining the negotiations and signing the TPP. Given the difficulty in breathing new life into NAFTA, Mexican business and government officials have explicitly maintained that the TPP would serve to consolidate its major export market and the North American production network, built since the Agreement came into effect in 1994 (de Rosenzweig Mendialdua 2015). ${ }^{19}$

\footnotetext{
${ }_{16}$ Acronym for an association of the five major emerging national economies: Brazil, Russia, India, China and South Africa.

17 Even though the BRICS is more a pragmatic than an ideological approach to international cooperation, such a grouping has taken steps towards a more institutionalized order by creating the New Development Bank (2014) and the Contingency Reserve Agreement (2014) (both components of BRICS' financial architecture became active in 2015). With these initiatives, the BRICS group is increasingly influential not only in Latin American financial matters but also in reshaping the wider global order in open challenge to US-led order (Contipelli and Picciau 2015; see also Simon Tisdall. "Can the Brics create a new world order?" The Guardian, March 29, 2012. https://www.theguardian.com/commentisfree/2012/mar/29/brics-new-world-order. Accessed December 15, 2016).

${ }^{18}$ In this issue, the NAFTA rules of origin for the automotive sector established $62.5 \%$ of regional content, whereas TPP establishes $45 \%$ (mainly due to pressure from Japan). This means that more Asian auto-parts suppliers could participate in regional production through their own assembling networks. This poses a significant challenge for the remaining local suppliers who will compete at a disadvantage with corporate groups and their usual suppliers. For the pharmaceuti$\mathrm{cal}$ industry, regional content was stipulated at 40 and $45 \%$ for certain products (see "Contenido regional de $50 \%$ en el TPP pide industria a SE (Ministry of Economy)", El Economista, July 29, 2015. http://eleconomista.com.mx/industrias/2015/07/29/contenido-regional-50-tpp-pide-industria-se. Accessed August 18, 2016; see also Government of Mexico "Tratado de Asociación Transpacífico (TPP)". http://www.gob.mx/tratado-de-asociacion-transpacifico. Accessed August 13, 2016.

19 Francisco de Rosenzweig Mendialdua served as Undersecretary for Foreign Trade, in the Ministry of Economy during the last stages of the TPP negotiations. See also: Government of Mexico "Tratado de Asociación Transpacifico (TPP)" ibid; Ministry of Economy (Mexico) “¿Qué es el \#TPP?” December 7, 2015. http://www.gob.mx/se/articulos/que-es-eltpp-17223. Accessed August 13, 2016; Ministry of Foreign Affairs (Mexico) “\#TPP ampliará la estrategia comercial de México" November 18, 2015. http://www.gob.mx/sre/articulos/tpp-ampliara-estrategia-comercial-de-mexico. Accessed August 13, 2016; Consejo Coordinador Empresarial (CCE, Mexico) "Reunión de seguimiento del Acuerdo Estratégico Transpacífico de Asociación Económica (TPP) entre la Secretaria de Economía y el sector empresarial" October 15 , 2015. http://www.cce.org.mx/reunion-de-seguimiento-del-acuerdo-estrategico-transpacifico-de-asociacion-economicatpp-entre-la-secretaria-de-economia-y-el-sector-empresarial/. Accessed August 13, 2016; "TPP abre oportunidades para México en Asia: Guajardo" El Economista, October 15, 2015. http://eleconomista.com.mx/industrias/2015/10/05/ ttp-abre-oportunidades-mexico-asia-guajardo. Accessed August 13, 2016; Confederación de Cámaras Industriales (CONCAMIN, Mexico) "CONCAMIN analiza procesos de negociación y exhorta al Poder Legislativo a aprobar TPP" Comunicado de prensa (Press release) July 27, 2016. http://concamin.mx/?paged=3\&post_type=comunicados Accessed August 13, 2016. CCE (http://www.cce.org.mx/) and CONCAMIN (http://concamin.mx/) are the largest and most influential private sector industrial associations in Mexico. Both associations participated along with several other sectorial associations and a few neoliberal "FTA specialists" in the so-called "next room".
} 


\section{Perspectives on diversification and upholding the US market}

The TPP is a potentially favorable instrument for economic diversification in Mexico. However, it is not clear whether Mexico's involvement is part of a strategic plan to link up with the Asian integration process or a reactive response aimed at safeguarding the privileges acquired under the now outdated NAFTA. In any case, the fundamental idea is that Mexico's linkage to Asia is through the US. ${ }^{20}$ Hence, the diversification promise by the TPP does not seem plausible.

Although difficult to ascertain, the apparent concentration of the Mexican economy probably reflects the triangulation of major business networks where some trade and investment activities purportedly linked to US firms are actually nodes of trans-regional production networks of Japanese and Korean firms, among others (Falck 2012). The TPP might accentuate such dynamics rather than help to develop new markets. Moreover, since US trade with several TPP member countries is marginal as well, triangulation is doubly irrelevant for Mexico.

Mexico has more free trade agreements than most countries in the world (11 with 46 countries) and, in theory, they were negotiated in order to diversify our economic relations. To be sure, according to Comtrade data, we have lowered the concentration of our exports to the US from $88 \%$ in 2000 to $81.2 \%$ in 2015 , while diminishing import concentration from 70 to $49 \%$. Nevertheless, the reduced concentration of our exports in this period is explained by the increased importance of China as a trade destination for Mexican exports-the Asian giant has moved from 19th to 3rd place. Besides, imports from China, a country with which we do not have a trade agreement, has jumped from 1.5 to $17.7 \%$ in 16 years. By contrast, since the Mexico-Japan Economic Partnership Agreement came into force in 2005, Mexican exports have grown in volume and value, but not its share with respect to overall exports (from 0.69 in 2005 to 0.79 in 2015). Something similar occurred with imports, shifting from 5.77 to $4.39 \%$ in the same period. It is possible to see such a pattern with the other agreements as well; this is partly why Mexican business leaders themselves have recognized that despite the large number of trade agreements most of them have been underutilized (CEE 2010: 185-6). In reality, therefore, the impact of commercial treaties as a trade diversification strategy has been comparatively marginal, though in some cases, such as the NAFTA, they may have had an impact on investment inflows. ${ }^{21}$ In view of the foregoing, it

\footnotetext{
${ }^{20}$ Secretaría de Economía (Ministry of Economy), “Memorias Documentales: TPP”, 2012. http://www.economia.gob. $\mathrm{mx} /$ files/transparencia/informe_APF/memorias/14_md_tpp_sce.pdf. Accessed April 13, 2016.

21 Besides boosting the volume of trade among signatories and the concentration of Mexican exports-imports, the NAFTA functioned as a detonator of inward foreign investment owing mainly to the privileged access to the large US market and cheaper labor costs provided by Mexico. Foreign direct investment (FDI) flowed not only from the US but also from Asia and Europe. Even before the NAFTA came into effect, large TNCs and their respective clusters of suppliers had already established operations on Mexican soil, especially in regions enjoying competitive advantages such as border states and cities (e.g., Nuevo Leon, Chihuahua, Tijuana and Mexicali) as well as more industrialized central states (e.g., Aguascalientes, Puebla, Mexico City, Queretaro, and the State of Mexico). However, increased foreign investment led to intra-industry and intra-firm trade among TNCs and their traditional contractors, which did not always prove beneficial for established Mexican suppliers; in the case of Japan and Korean FDI in Mexico, the NAFTA consolidated these trade dynamics. According to Comtrade data (http://comtrade.un.org/), in 2015, Mexico imported US\$ 17,368 billion from Japan and US\$ 14,619 billion from Korea, while exporting only US\$ 3017 billion and US\$2770 billion to these countries, respectively. In both cases, 70 to $80 \%$ of total imports from these Asian countries were comprised of parts and components assembled by Japanese and Korean companies located in industrial parks in Mexico and re-exported as final goods, mostly to the US, whereas nearly $80 \%$ of Mexican exports to those countries consisted only of primary and semi-manufactured products. Trade volume and composition have painted an unfavorable picture of Mexican industrial producers, who represent less than a $5 \%$ share of global production networks. Contrary to expectations, Mexico did not attract Japanese FDI to any significant extent in the five years following the adoption of the Japan-Mexico FTA in 2005. That is, no significant positive correlation has been demonstrated between FTAs and increased investment (López Aymes and Salas-Porras 2012; Bancomext 2015).
} 
is unclear what the impact of the TPP on Mexican economic and social development would be.

It is true that total trade generally improves after the enactment of a trade agreement, but not always as a result of additional high-value exports from Mexican firms. An explanation may lie in the fact that Mexican entrepreneurs have proven to be poorly informed about the advantages, risks and obstacles involved in international trade. This, combined with an absence of real interest in exploring new business prospects in Asian markets, as well as an inability to satisfy demand regarding quality/quantity and an outright lack of strategic planning, has meant that the private sector rarely ventures beyond the comfort zone of the US market. The field of international trade is thus left wide open to non-Mexican entrepreneurs.

Clearly, Mexico-US economies are well integrated and production networks involving Mexican and non-Mexican companies are firmly established, which has led to an extraordinary dependence on the US market. Two examples provide a telling contrast to the case of Mexico. Trade between Austria and Germany-two highly integrated economies-is much less concentrated, with Austrian exports to Germany representing $29 \%$ of their total exports, and imports from Germany accounting for 37\% of their total imports. Korea and China is a similar case. While the highly desirable Chinese market is the most important destination for Korean exports, it still captures only a quarter of the total, mostly consisting of value-added goods and parts for re-export; slightly over $10 \%$ of Korean exports go to the US. By way of comparison, imports from China are 17\% of the Korean total, followed by $10 \%$ from Japan and $8.7 \%$ from the US (Comtrade). As can be noted, while it is natural that the US is Mexico's largest trading partner, bilateral trade between these countries represents a highly disproportionate percentage of total Mexican trade.

In political economy, this excessive dependency reflects the regional division of labor and the logic of economic concentration. Nevertheless, it leaves Mexico at a disadvantage when it comes to understanding and developing other market networks. Clearly, judging from the Mexican experience, incentives in the form of formal trade agreements have not succeeded in encouraging local entrepreneurs to take risks or even attempt to tackle the Asian TPP markets lauded by the Mexican government as representing a great opportunity given the rapid economic growth in that region. It is worth bearing in mind that one country's exports are another's imports. The focus by the government and various business associations on export diversification misses the point that imports are a key component of trade, particularly as regards enhancing competitivity and acquisition of technology. It is risky to assume that the commercial deficit resulting from intraindustry trade and tied to transnational networks will eventually be offset by exports to the US. This would come at the expense of weakening the technological and production capacities of local producers. For imports to become a source of competition encouraging efficiency and serving as a channel for technological diffusion, require certain conditions: adequate industrial as well as S\&T policies, a balanced patent system, and a strategic vision from the business community. However, industrial policy, access to technology, and capital formation in Mexico rely heavily on foreign investment. While the patent system is strong, it mostly benefits TNCs. As a consequence, the Mexican business community seldom explores new markets and business opportunities, nor does it 
invest in $R \& D$, in part due to the political coalition that resulted from the liberalization and internationalization of Mexican economy in the 1980s and 1990s (Shadlen 2012). These circumstances make it challenging to fulfill the diversification opportunities promised by the TPP. ${ }^{22}$

Another argument against the TPP as an instrument for diversification is that Mexico already enjoys active agreements with most of the other 11 members: Chile, Canada, the US, Peru, and Japan. In fact, with Peru and Chile, Mexico also shares membership in the Pacific Alliance. Given the small and diverse group of participants, the gains from access to new markets have been negligible for Mexico. We do not have trade agreements with Australia, Brunei, New Zealand, Vietnam, Singapore or Malaysia, but our economic relations with these countries are marginal, ${ }^{23}$ and there are no signs that this will change in the near future to warrant participating with them in strategic initiatives, at least not in the economic arena.

The current discourse in favor of the TPP tends to highlight the economic importance of the partnership and its weight in terms of wealth, international trade and investment. However, most economic data are inflated as a result of including the US and Japan within the aggregate. If we remove the US from the calculations, the remaining TPP members would present quite a different picture, even with Japan still included among them. For instance, of the more than $\$ 27$ trillion gross domestic product (GDP) of the TPP members, the US alone accounts for approximately US $\$ 17$ trillion. Hence, referring to the TPP as a market of nearly 800 million people is an overstatement, as the US, Japan and Mexico account for nearly two-thirds of the total population. Besides, without the US, the share of trade relations among the remaining TPP partners is minimal (see Table 1), with the other ten partners making up barely $4.83 \%$ of total Mexican export destinations. If additionally we remove Canada and Japan, with whom we also have FTAs, the share would fall to $1.48 \%$. Finally, in order for the TPP to enter into force it must be ratified by at least the number of countries that together account for $85 \%$ of the group's GDP: that is, Japan and the US. If either of these countries fails to ratify the Agreement, it will not take effect.

I also considered the following question: to what extent does the TPP foster diversification of FDI sources, in theory, crucial to technological diffusion? FDI is a relevant factor for constructing global production chains and providing access to new technologies. In this regard, establishing strong IPR regimes can serve to attract more FDI and trigger a virtuous cycle of investment and growth. However, while this works well among developed countries, the situation is less clear in circumstances involving asymmetrical trade relations (Schneider 2005). In the case of Mexico, the NAFTA negotiations in the early 1990s not only consolidated a privileged relationship with the most important market at that time; it also helped to attract foreign companies from countries other than the US and Canada. Those countries were motivated by trade diversion concerns because of the regional content provisions in the Agreement, and by fears of being left outside North American production networks. However, as a result of the negotiation process, the

\footnotetext{
${ }^{22}$ In Mexico, most R\&D is carried out by public universities and supported with public funding (see OECD Main Science and Technology Indicators) http://stats.oecd.org/Index.aspx?DataSetCode=MSTI_PUB. Accessed August 19, 2016.

${ }^{23}$ In 2014, the Mexican exports to some TPP partners accounted for the following proportions: Australia, 0.2539\%; Brunei, 0.00065\%; Malaysia, 0.0492\%; New Zealand, 0.0249\%; Singapore, 0.1331\%; and Vietnam, 0.0435\% (see: UN Comtrade Database http://comtrade.un.org/. Accessed April 14, 2016).
} 
Mexican government was forced to revise its patent system unilaterally and give up authority on all matters pertaining to technology (Article 27 of the Agreement on TradeRelated Aspects of Intellectual Property Rights-TRIPS) (Aboites and Soria 2008; Shadlen 2012). ${ }^{24}$ Until then, the Mexican government had held control over domestic regulations on import substitution. The revised patent system offered FDI from different sources an additional incentive to select Mexico, thus effectively diversifying the country's sources of industrial capital. Nevertheless, FDI inflow to Mexico-more than 55\% came from North America ${ }^{25}$ - did not wholly translate into effective knowledge sharing, access, or accumulation, and this may have been attributable to the new patent regime as well as to weak S\&T policy. Even though foreign investment and patent applications increased after NAFTA was signed, the proportion of Mexican applicants remained negligible compared to that of other foreign applicants (see Graph 1). Even if major trade agreements such as NAFTA do attract foreign investment, this does not mean that technology is shared or developed locally by transnational firms, precisely because incentives entail the protection of technological expertise rather than rendering it available and usable by newcomers in a timely fashion. Therefore, notwithstanding its advantages regarding foreign investment diversification, the TPP poses a significant challenge to local firms and knowledge producers for catching up, upgrading or innovation, even if talented and highly qualified human resources are available.

In light of the above, what do the advocates of the TPP really mean when they claim that it will allow "preferential access to 11 of the most important economies in the world?" ${ }^{26}$ Aside from protecting TNC-owned IPRs, it is far from certain that diversification of FDI sources would contribute to the technological upgrading of the Mexican industrial base. These considerations lead us to question the strategic value of being a member of the TPP in the context of export market diversification, and the presumed advantage of being an active player in global supply chains for both the US and the Asia Pacific region. Therefore, the argument that TPP is desirable as an instrument for trade and investment diversification is not convincing.

\section{The TPP as a problem for Mexican domestic technology development and innovation}

In both academic and industrial practice, an implicit and explicit debate exists over the meaning of fair, trustworthy and transparent economic systems and rules for establishing a "level playing field". This is a crucial matter for the political economy of development, because rules can either hinder or stimulate progress in S\&T and innovation. The common perspective holds that the only advantageous and sustainable way for a country to develop and become part of the capitalist production system is by finding a way to consolidate its own capacity for technology development and innovation (Olwan 2013). That is why the establishment of rules and policies for nurturing and stimulating local research in S\&T is vital for autonomous development, and for allowing the productive sector to harvest the gains from its own efforts.

\footnotetext{
${ }^{24}$ See Footnote 4.

25 Ministry of Economy: "México registró 21,585.6 mdd de Inversión Extranjera Directa," November 24, 2015. http:// www.gob.mx/se/articulos/mexico-registro-21-585-6-mdd-de-inversion-extranjera-directa. Accessed August 17, 2016.

${ }^{26}$ Government of Mexico, “Tratado de Asociación Transpacifico (TPP)”, ibid.
} 


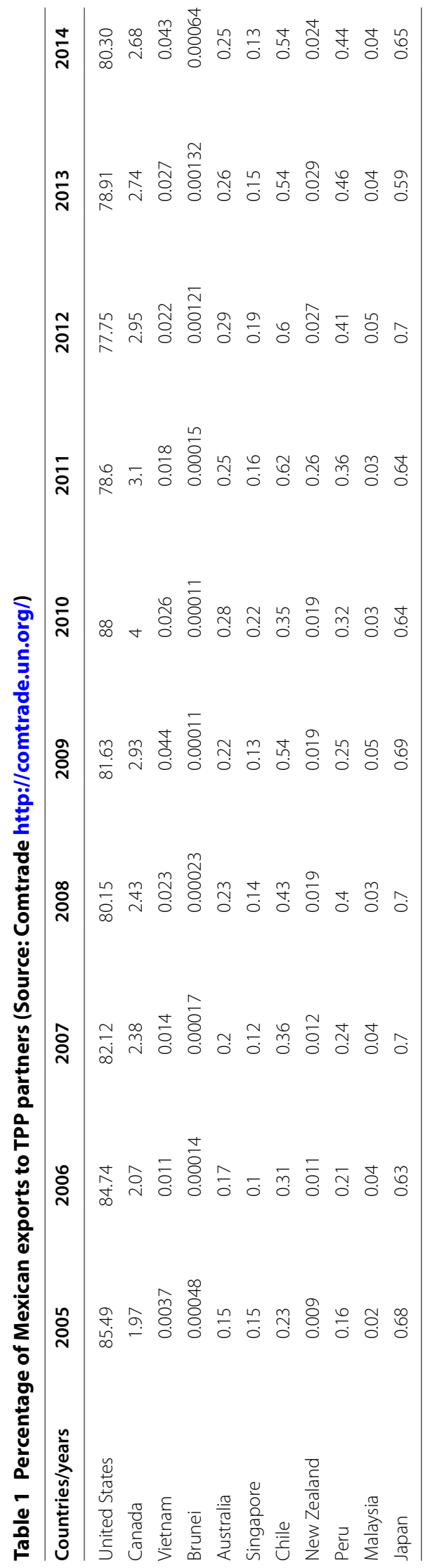


Chapter 18 of the TPP concerns IPRs. It covers a significant range of issues related to intellectual creation in the artistic, scientific, industrial and marketing areas, as well as in more collective endeavors involving traditional knowledge and its applications. It also includes specifications on copyrights, trademarks and geographical indications, some of which are important to preserve. Among the main features and novelties of the IPR provisions on patents (which confer limited, rights of exclusion to owners of knowledge) and trade secrets are (a) the patentability of processes and new uses of known pharmaceutical, chemical, agrochemical and biological products including medicines; (b) limits on justifications for revoking patents; (c) compensation for restrictions and unreasonable delays in patent concessions; (d) criminal penalties for trade secret theft, trademark counterfeiting and copyright piracy; and (e) clarifications regarding state-owned enterprises. The new standard for leveling the IPR playing field establishes 10 years of data protection for agrochemical products; 5 years for new pharmaceutical products; 3 years for clinical trials (undisclosed) of new indicators, formulas and administrative methods; and 5-8 years for pharmaceutical and biological agents. It also follows Article 39.2 of the TRIPS Agreement in setting no time limits for the protection of trade secrets.

The Objectives section (Art. 18.2) states that "The protection and enforcement of IPRs should contribute to the promotion of technological innovation and to the transfer and dissemination of technology, to the mutual advantage of producers and users of technological knowledge and in a manner conducive to social and economic welfare, and to a balance of rights and obligations." The Mexican negotiators argue that they made every effort to ensure a balance between the interests of producers and those of society, notwithstanding the intense pressure exerted by TNCs and some sectoral associations such as AMIIF. $^{27}$ The relevant chapters also synthesize a large number of international agreements and norms of which Mexico is already a signatory, although there are some novelties including rules for digital technologies and the acceptance of the International Union for the Protection of New Varieties of Plants (UPOV).

In discussing the potential impact of the TPP on inhibiting or stimulating domestic technological development, the debate should refer to economic history, and recognize that the governments in what are now regarded as advanced economies have always played an active role in such development processes. For example, from the beginning of their respective industrialization processes, the Japanese, Korean and Chinese governments recognized that domestic technological development was the key to climbing the industrial ladder, ensuring that their national firms captured the value added generated from their own investments and production (Ernst 2015a; He 2015; Jung and Mah 2014;

\footnotetext{
27 The AMIIF (Asociación Mexicana de Industrias de Investigación Farmacéutica, A.C.) represents more than 40 leading pharmaceutical and biotech R\&D firms with presence in Mexico and worldwide. See also: "Productos sensibles, el tema a tocar del TPP: Guajardo" El Economista, July 30, 2015 http://eleconomista.com.mx/industrias/2015/07/30/productos-sensibles-tema-tocar-tpp-guajardo. Accessed August 13, 2016; CCE "Reunión de seguimiento del Acuerdo Estratégico..." op cit., and personal communication with one of the IP chapter negotiators who requested anonymity. A relative success of the negotiators was to limit the period of protection for undisclosed tests or other data (Article 18.50) from the original 12 years requested by the pharmaceutical industry to 5 years, and to 8 years for biologics, under Article 18.52.1(a) (Biologics). In order to implement and comply with Chapter 18 provisions, Mexico agreed upon the following transition periods:

1. Article 18.7.2(d) (International Agreements), UPOV 1991, 4 years (currently Mexico is part of the 1978 Convention);

2. Article 18.47 (Protection of Undisclosed Test or Other Data for Agricultural Chemical Products), 5 years;

3. Article 18.48.2 (Patent Term Adjustment for Unreasonable Curtailment), 4.5 years;

4. Article 18.50 (Protection of Undisclosed Test or Other Data), 5 years;

5. Article 18.52 (Biologics), 5 years; and

6. Section J (Internet Service Providers), 6 years.
} 


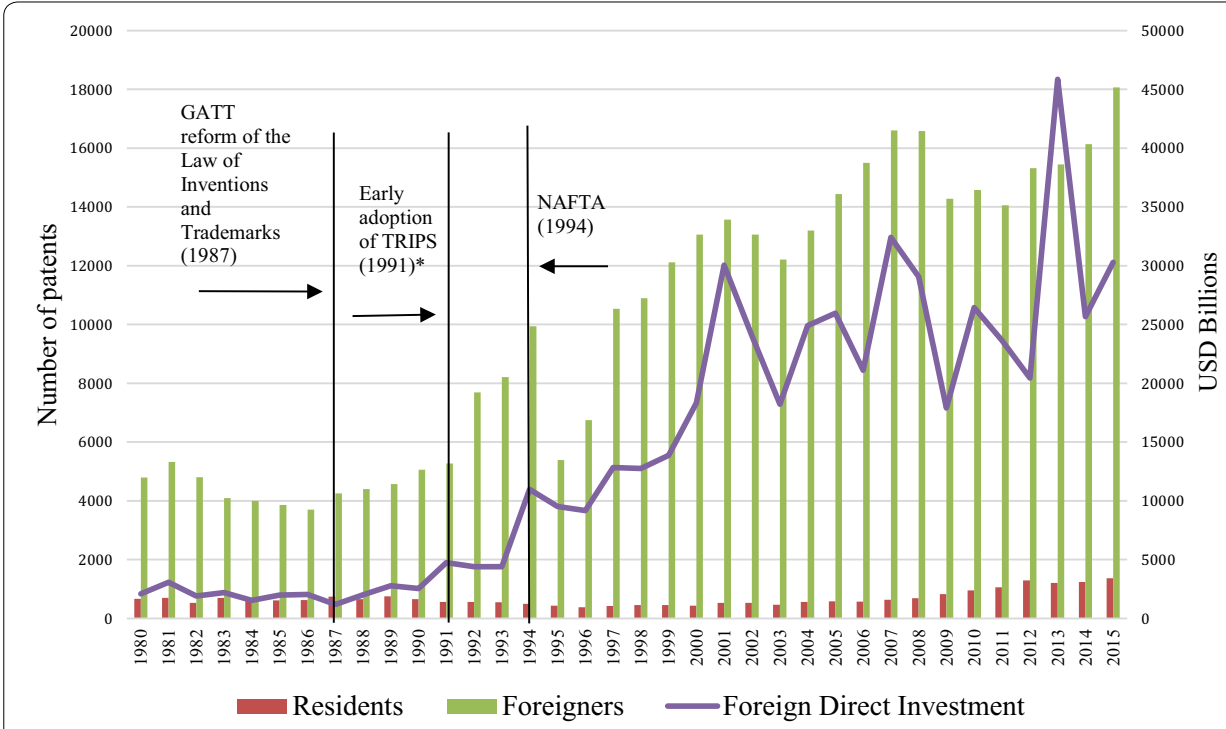

Graph 1 Patent applications from Mexicans (residents), foreigners and FDI in Mexico (1980-2015). Asterisk This was enforced by the 1991 Law for Promotion and Protection of Industrial Property. Source World Bank http://data.worldbank.org/indicator/BX.KLT.DINV.CD.WD; Aboites and Soria (2008); IMPI (2016: 6)

KPR 2007; Yoon 2014; Lee 2012; Liu and Cheng 2011). Before them, the United States, ${ }^{28}$ Germany, France and other European powers had done the same, and continued to finance and foster research and development programs thereafter. In this context, the demand by the TPP for non-intervention and for eliminating government subsidies sounds rather hypocritical (Chang 2002, Ch. 4; Chang and Grabel 2004, Ch. 8; Atkinson 2015). More recently, several South East Asian countries such as Singapore, Malaysia and Vietnam have followed this path, although with more difficulty as a result of the international regulatory system which was either nonexistent or substantially weaker in the postwar years. Subsequently, in the 1970s and 1980s, issues such as IPRs, subsidies, and restrictions on government financing for infant industries were added to the GATT agenda (DiCaprio 2010; DiCaprio and Gallagher 2006).

At various times, some East Asian countries established strategic development regulations to partner FDI with developmental goals. These encouraged technology transfer and the direct participation of local personnel in technological development processes (Dent 2003; He 2015; Lee 2005). Such a vision was coupled with an economic strategy integrating industrial, education and S\&T policies in a fairly efficient way, in spite of pressures from global market forces and international regimes (He 2015; Liu and Cheng 2011; Park 2012). But most importantly, they did so while pursuing concrete national objectives such as the formation of domestic automotive, pharmaceutical, electronics, and aerospace industries, among others (López Aymes 2010). Consequently, in forbidding states from playing a leading role in the formation and support of national industries (e.g., through the rules of origin in Chapter 3 and public sector procurement in Chapter 15) and reserving access to knowledge and new technologies exclusively to its own private

\footnotetext{
${ }^{28}$ Among others, see the Vannevar Bush report "Science, The Endless Frontier." It is unambiguous in its findings and arguments about spending on research and development as a matter of US national security. Report is available at: https://archive.org/stream/scienceendlessfro0unit\#page/n0/mode/2up. Accessed April 13, 2016.
} 
companies by imposing a patent system which privileges and prolongs the monopoly by foreign enterprises, the TPP would serve to institutionalize a relationship of dependence and would formalize a system rife with disparities, inequity, and deficiencies.

In other words, the deficiencies of the IPR rules established in the TPP favoring transnational firms mostly from advanced economies, would hamper domestic technology development, knowledge accumulation and access to new technologies. As stated by Sebastian Herreros from the Economic Commission for Latin America and the Caribbean (ECLAC):

US business groups have called to use the TPP negotiations to set a new, higher standard for protection of IPRs, thus raising the protection levels agreed in previous US bilateral FTAs (which already exceed in several aspects those agreed in the WTO's Trade-Related Aspects of Intellectual Property Rights agreement). Intellectual property is an area in constant expansion in a world economy which is increasingly technology-and knowledge-driven. Accordingly, the US-as the world's largest net exporter of intellectual property-has pursued since the 1980s a policy of continuous upward protection of IPRs in its trade negotiations, in which the last FTA negotiated (in this case the one with Korea) becomes the de facto baseline for future talks (Herreros 2011: 31-2).

Among the most salient trade-related rules in the TPP are the ones concerning IPR protection in the areas of industrial, pharmaceutical, biological and agricultural technologies. It is understandable that firms should seek to curb piracy, since allowing a temporary monopoly on knowledge tends to stimulate investment in research and innovation with the expectation of returns from R\&D expenditures (Ordover 1991). However, the prevailing outlook of the TPP privileges the attribution of exclusive rights to authors and producers over safeguarding the rights of the general public and the advancement of those lagging behind-many of them trailing as a consequence of the way in which the capitalist system has evolved in the postwar era. Moreover, the possibility of patenting new applications as well as novel methods and processes for the use of products already in the market may have an adverse effect on secondary patents. This so-called "evergreening" effect could not only prompt anticompetitive practices, but also discourage innovation by permanently obstructing access to new technologies or by charging large sums of money for access to their patents, thus making overall production processes even more costly and inefficient (Stiglitz 2006, Ch. 4). Additionally, it could encourage strategic patenting, which precludes innovation and can be used as a market deterrent (Ernst 2015b; Girard 2012). This is anything but conducive to reducing the technological gap and improving human wellbeing.

From a wider perspective, it is not yet clear how the TPP could accomplish its objective of "contribut[ing] to the promotion of technological innovation and to the transfer and dissemination of technology" as stated in Art. 18.2. The opposite is more likely, and the institutional constraints of the Agreement may end up limiting the possibilities for domestic technology development and inhibiting innovation in national industries, as TNCs seldom transfer technology voluntarily. Even if Mexico is home to a number of leading firms in the electronics, pharmaceutical, automotive, and aeronautics industries, among others, the number of patents generated by Mexican companies is minuscule in 
comparison with those generated by their foreign counterparts (see Graph 1 above). Moreover, the main Mexican applicants are made up of public universities and research institutes (IMPI 2016: 15) with very weak linkages to the private sector. It should be noted that the growing presence of TNCs has not led to the desired stimulation of national industry in high-value segments; their main contribution has been the creation of jobs in the low and semi-skilled workforce, along with a few top management positions. It is clear that the low level of public and private investment in $R \& D$ is largely responsible for the poor performance in patent applications. This may reflect three things: first, that the Mexican S\&T policy is shallow and generally lacking in financial resources ${ }^{29}$ second, that the strong IPR regimes introduced in the 1990s have curtailed the utilization of new technologies by domestic firms and have obstructed their chances of finding incentives and strengthening their capabilities for engaging in R\&D, and third, as Shadlen (2012: 303) argues, "economic liberalization and internationalization of the economy, strengthened a coalition based on a low-technological form of integration into the global economy, and the same processes have withered away the coalition that might push for an alternative project". Under these conditions, it has often been necessary for Mexican firms to purchase patents, or to wait at least 20 years for them to expire (according to TRIPs to which TPP's Chapter 18 is linked), an excessively long period considering the pace of technological innovation.

The new IPR rules in the TPP-labeled by Leonardo Burlamaqui as "TRIPs-plus with steroids"-were set to establish even higher standards than those mandated by the WTO-TRIPs. ${ }^{30}$ Notwithstanding, Mexican negotiators argue that they actually soften IPR pressure. ${ }^{31}$ The ongoing knowledge monopoly primarily favors the large corporations of the advanced economies, with the duration of patents often stretching over arbitrary and unreasonably long periods (Stiglitz 2006, Ch. 4). While the IPR chapter in the Agreement, particularly the section pertaining to patents, would surely bring greater certainty to foreign investors in Mexico, it would most likely prevent the state from upgrading domestic technology development and stepping up innovation by national industrial and scientific communities.

\section{Results and discussion}

The TPP is designed to profoundly transform the interregional trade and investment landscape, and would challenge the capacity of many of its members to compete with the "big players" using their rules. Mexico has played the game before and is a champion

\footnotetext{
${ }^{29}$ The current National Development Plan for Mexico 2012-2018 includes the goal of increasing private investment in R\&D and achieving 1\% of Gross Domestic Expenditure for Research and Development (GERD) (as opposed to an average of $2.37 \%$ for the OECD countries in 2011). To this effect, the main strategy stated by the government consists in producing and strengthening human capital available to harness knowledge transfers; see Diario Oficial "Programa Especial de Ciencia, Tecnología e Innovación 2014-2018”, available at: http://www.dof.gob.mx/nota_detalle.php?codig $o=5354626 \&$ fecha $=30 / 07 / 2014$. Accessed August 19, 2016. Mexican GERD grew from 0.43\% at the start of President Enrique Peña's term in 2012 to $0.54 \%$ in 2014 (in contrast to an average of $2.38 \%$ for the OECD, and $4.29 \%$ for Korea). In $2014,73.56 \%$ of the Mexican GERD was financed by the government vs. $23.76 \%$ by the industry (as opposed to 27.83 vs. $60.92 \%$, respectively, for the OECD, and 22.96 vs. $75.33 \%$, respectively, for Korea). In 2014, financing for GERD as a percentage of GDP was $0.40 \%$ by the government vs. $0.13 \%$ by the industry (compared to 0.66 vs. $1.45 \%$, respectively for the OECD as a whole; and 0.99 vs. 3.23\%, respectively, for Korea). Among the OECD countries, Mexico indicates one of the lowest ratios of researchers per thousand labor force, with a total of $0.78 \%$ in 2011 (no record is available thereafter) as opposed to $7.21 \%$ for the OECD as a whole. Korea indicated $11.51 \%$ in 2011 and $13.02 \%$ in 2014 (OECD Main Science and Technology Indicators, op cit.).

30 See Footnote 5.

31 Personal communication, September 14, 2015.
} 
at accumulating trade agreements. However, the Mexican experience has not shown that FTAs provide any particular advantage to national exporters, except for businesses related to raw materials, natural resources, and low-tech, low-value intermediate goods. Some firms supply goods and services within global production networks, but in the second and third tiers or below.

Encouragingly, the 2012-2018 National Development Plan of Mexico considers the Asia Pacific area to be a key region for development; however, other than jumping on the TPP bandwagon, it is unclear that the Mexican government has any concrete plans for engaging strategically with Asia as a way of helping to upgrade its economic relations and foster technological development. Accordingly, joining the TPP, or any other similar treaty if the Agreement is ultimately rejected by the US, would be problematic if the purpose were to alleviate structural deficiencies in the Mexican economy. Crafting a comprehensive economic policy to address industrial and trade concerns, as well as to promote science, education and domestic technological innovation, would be a highly effective way of positioning Mexico to compete internationally and take advantage of the Asian integration process. This is the strategy that East Asian economies have followed so successfully, and continue to pursue today.

This leads us to the second major issue discussed in this paper: the prospect of enhancing technological capacity and innovation within a strict IPR regime. Industrial policy plays a key role here, but in Mexico and elsewhere this is often tied to systems of patronage and focused almost exclusively on clientelism. A well-conceived strategic industrial policy should set explicit goals for development and avoid becoming ensnared in "money politics". Industrial policy can be functional yet focused on particular activities such as investing in $S \& T$ as well as supporting $R \& D$ and innovation in targeted industrial sectors. This opens up possibilities for exploiting as yet uncrowded niches including cleanenergy and energy-efficient environmentally sustainable transportation, and so on. For this to happen, however, a different structure governing knowledge and technology in the public interest is essential (Burlamaqui 2014).

As it is, a level playing field under the prevailing conditions of asymmetrical industrialization will always work against the interests of less developed players (Kim et al. 2012). While even a well-designed and comprehensive economic policy might not succeed in restraining already established TNCs, it should at least aim to reduce technological dependency. Furthermore, before joining the TPP it would be indispensable for Mexico to initiate international cooperation schemes that truly advance scientific development and the capacity for innovation-in marked contrast to the sort of conditional cooperation currently prevailing, often involving contracting with foreign services or suppliers for infrastructure or industrial projects. In short, absent an effective, comprehensive and visionary strategy for abetting S\&T, infant industry development, education, antimonopoly laws, foreign investment, fair trade competition and public sector procurement, joining agreements such as the TPP will only serve to institutionalize dependency.

Accordingly, the debate in the political arena among legislators, executive officers, stakeholders and civil society must question the wisdom of joining an agreement that would further constrain the ability of Mexico to compete in the high technology sector-if, indeed, such an effort is being seriously considered at all. In any case, should the TPP be approved in the US and, consequently, in Mexico, it is industries that are largely 
dominated by TNCs who would benefit the most, including the automotive, pharmaceutical, electrical and electronics sectors, and, most likely, agro-business (especially as regards seeds and biotech). This would further entrench foreign influence on Mexican economic policy. I dispute the wisdom of both ratifying the TPP and embracing the idea that "being out of it would mean to be left out of the chance to integrate and access market opportunities that weren't available before". What those new market opportunities might be is far from clear. On the contrary, IPR rules would likely confine Mexico's "opportunities" to the usual low-value exports, with high-value exports generally being handled by foreign firms and their networks. Moreover, these foreign entities push to maintain the current knowledge monopolies and pursue strategic patenting. Finally, the TPP has been explicitly advocated by the Mexican government to safeguard the position of Mexico in the US market. Yet it already enjoys a secure trade relationship with the US, without the need to further entrench our peripheral role in the regional division of labor. Mexico is also signatory to major IPR conventions, so why make any further concessions?

Under present conditions, joining the TPP would most likely place Mexico in much the same position it currently holds within the WTO, that is, needing to take advantage of every opening provided under current rules governing knowledge in order to support infant industry as well as promote R\&D and innovation. As put by Amsden and Hikino regarding the WTO:

All in all, the liberal bark of the WTO appears to be worse than its bite. The neodevelopmental state can continue to subsidize new industries where necessary and to ensure that subsidies are result-oriented through the imposition of performance standards. Instead, the most coercive part of the new international economic order is informal. Coercion takes the form of political pressure by the North Atlantic on emerging economies to open their markets... (Amsden and Hikino 2000: 110).

If Amsden and Hikino's argument that "latecomers lack a vision to guide them in responding to this pressure" holds true, then we can perhaps find comfort in paraphrasing Alexander Wendt to the effect that policy space is what governments and societies make of it: it is a perception, a political construction informed by ideas, discourse and sometimes self-awareness, or a self-imposed position in the system. What is very real, though, are the newly established rules that dictate what countries can or cannot do. As asserted by Carolyn Deere (2009), a development-oriented IPR policy must be consistent, coordinate relevant government agencies in collaborative work, develop highlevel legal expertise, engage civil society, and frame issues in a way that is accessible and appealing to the media and to the general public. As one of its central functions, such a policy must balance broad access to and utilization of knowledge with fair and reasonable protection for certain intellectual products. Finally, such a policy must defend the public interest against monopolies, particularly with regard to pharmaceutical and biotech products.

This research had its limitations, however, most importantly, the fact that, at the time of writing, the TPP was still under revision by stakeholders and civil society in signatory countries, and great skepticism overshadows its fate after Donald Trump's victory in presidential elections. As a result, the conclusions on implications for national policy 
may appear to be speculative. Nevertheless, my critique is grounded in historical evidence regarding the two main issues addressed in this paper: the prospects for diversification and the alleged benefits of the IPR rules proposed by the TPP. My research in both areas indicates that the Agreement would be adverse to national goals including economic growth and improved labor conditions. Another limitation to this work was lack of access to a wide range of policy-makers and negotiators, most of them still in office. Direct contact with individuals involved in negotiating the Agreement would have permitted a more qualitative research design. The possibility of conversing with insiders in an environment sheltered from political pressure and non-disclosure commitments would have deepened our understanding of the nuances of the TPP. A more open disposition will probably ensue once the TPP is either ratified or rejected, particularly if relevant negotiators remain in office. Furthermore, evaluating diversification lies beyond the scope of this paper. It is a long-term, complex and multifaceted process, well beyond any formal agreement, which requires follow-up longitudinal research to assess the impact of the TPP on deconcentrating economic relations. Nonetheless, the assertion by Mexican authorities that the TPP would serve to strengthen North American production networks suggests that diversification is seen as a potential secondary effect, not as a goal in itself. Consequently, no additional policy initiatives to foster diversification can be expected from the Mexican government, with authorities apparently focused on attracting foreign investment and increasing imports over the medium term, rather than on creating market opportunities for Mexican exports and investment abroad.

\section{Conclusions}

This paper has examined the origins and nature of the TPP, and expresses a twofold critique: first, that the Agreement would hardly contribute to economic diversification and, second, that rules governing IPRs would reduce the potential for implementing policies in favor of domestic technological development, and would instead privilege the longterm monopoly interests of TNCs. Given the apparent exhaustion of NAFTA-which has neither reduced poverty levels nor strengthened capacity building in Mexico-the government and various members of the private sector community in Mexico view the TPP as a way of preserving their share of the US market. However, given the characteristics of our current trade structure, the argument that the TPP can be an instrument for diversification and for enhancing access to the Asian market seems neither realistic nor plausible-aside from participating in the triangulation of East Asian business networks throughout the Mexican and US markets. In addition, not only would the TPP have a marginal impact on diversification (or perhaps even economic growth [see Capaldo et al. (2016)], it would also tie Mexico's political economy even more firmly to Washington's geopolitical strategy-including its current efforts to "contain" China-with rules that undermine Mexican foreign policy autonomy and its prospects for developing domestic technological capabilities. As Bernard Girard (2012) remarks, "Regulations change from one country to the other, and what is good for America is not necessarily good for others. European and Asian governments could look at other ways to stimulate innovation". Other studies like that of Kim et al. (2012) and Shadlen (2012) support this point, concluding that patent protection enhances innovation and economic growth in countries 
where the capacity to conduct innovative research already exists, but does not benefit countries without such capacity.

To be sure, some chapters of the TPP might result in positive outcomes, namely enhanced environmental and wildlife conservation, ${ }^{32}$ greater transparency and a curbing of corruption, trademark, geographical indicators and copyrights protection, reduced abuse by state-owned enterprises. Other chapters, such as 21 and 23 on Development, fail to spell out specific measures, and reflect mere wishful thinking based on neoliberal values. Chapter 23, for example, which devotes a section to technology, constitutes a vague defense of the market economy, and does not recognize that encouraging greater public and governmental involvement in S\&T is inconsistent with maintaining the current monopoly of knowledge. This highlights a striking paradox regarding IPRs: the TPP claims to develop technological capabilities by cultivating highly skilled human resources (scientific and managerial), but imposes strict and lengthy monopolist rights to knowledge. Being required to purchase patents or wait for their expiration or restrict access to valuable data for clinical research is not compatible either with the aspiration to enjoy fair and open competition or with efforts to develop the capacity for participating at a higher level of global production. Instead, TPP rules on IPRs leave very limited institutional space for local companies and research institutions to achieve significant innovations, cultivate human resources in S\&T, and enforce IPR rules with some degree of discretion. As in the case of NAFTA, opportunities to catch up would be limited, and the development of technology and human resources in Mexico would continue to lag. In the past, countries like South Korea, and even Germany and Japan in the $19^{\text {th }}$ Century, were able to thrive under a more flexible IPR system. China is thriving precisely because it chose an alternative path to the dominant global IPR system and pursued a S\&T policy with the specific aim of catching up with the advanced economies, notwithstanding resistance from some international players. Nevertheless, it does not seem that the costbenefit relationship would be favorable for Mexico, at least as regards the issues elaborated here-issues which are crucial for the prospects of long-term development.

Finally, the prospect of TPP is bleak and it is very likely it will not be ratified by US. Despite such probable fate, it can be expected that the stakeholders who push the TPP agenda (i.e., TNCs) will resume their activism in due time, perhaps with a "new" proposal, but surely resembling the controversial Agreement. In that case, I think the critical view on IPR articulated here may still be valid.

\footnotetext{
Acknowledgements

I would like to thank Janette Pérez Fernández, Edith Yazmin Montes Incin, and Miguel Ángel Uribe Hernández for their valuable research assistance and encouraging interest on this paper, and the two reviewers for their helpful comments and suggestions.

This article is an extended version of a note elaborated in Spanish for the Heinrich Böll Foundation (Mexico branch) with the purpose of non-academic non-profit diffusion (see http://mx.boell.org/es/2016/01/27/mexico-y-el-tpp-unainterpretacion-critica-0). Accessed August 22, 2016.
}

\footnotetext{
${ }^{32}$ For instance, see Ron Nixon and Coral Davenport, "Environmentalists Praise Wildlife Measures in Trans-Pacific Trade Pact" (The New York Times, October 5, 2015, http://www.nytimes.com/2015/10/06/business/environmentalistspraise-wildlife-measures-in-trans-pacific-trade-pact.html? $r=0$. Accessed April 14, 2016). However, even these themes have not gone unchallenged: cf. Sierra Club, "TPP Text Analysis: Environment Chapter Fails to Protect the Environment (October 29, 2015, http://www.sierraclub.org/trade/trans-pacific-partnership. Accessed April 12, 2016); David Vivas Eugui, "Los recursos marinos y la biodiversidad en el TPP: ¿un balance sostenible?" Puentes (International Centre for Trade and Sustainable Development, February 24, 2016, http://www.ictsd.org/bridges-news/puentes/news/los-recursosmarinos-y-la-biodiversidad-en-el-tpp-\%C2\%BFun-balance-sostenible. Accessed April 12, 2016).
} 


\section{Competing interests}

The author declares that no competing interests.

\section{Funding}

Dr. Juan Felipe Lopez Aymes, a research fellow at the Regional Center for Multidisciplinary Research has no access to institutional funding.

Received: 2 May 2016 Accepted: 27 December 2016

Published online: 05 January 2017

\section{References}

Aboites, Jaime, Mario Capdevielle, and Manuel Soria. 2011. Propieded intelectual y política industrial. In La UAM ante la sucesión presidencial: Propuestas de política económica y social para el nuevo gabierno. Mexico City: Universidad Autónoma Metropolitana.

Aboites, Jaime, and Manuel Soria. 2008. Economía del Conocimiento y Propiedad Intelectual. Mexico City: Siglo XXI, Editores

Aggarwal, Vinod K. 2016. Mega-FTAs and the Trade-Security Nexus: the Trans-Pacific Partnership (TPP) and the Regional Comprehensive Economic Partnership (RCEP). Honolulu: East-West Center.

Amsden, Alice, and Takashi Hikino. 2000. The bark is worse than the bite: new WTO law and late industrialization. Annals of the American Academy of Political and Social Science 570: 104-114.

Armstrong, Shiro. 2011. China's Participation in the Trans-Pacific Partnership. East Asia Forum.

Atkinson, Anthony B. 2015. Inequality: What can be done? Cambridge: Harvard University Press.

Baldwin, Richard, Masahiro Kawai, and Ganeshan Wignaraja (eds.). 2013. Future of the World Trading System: Asian perspectives. London: Centre for Economic Policy Research; VoxEU.org.

Bancomext. 2015. México y Japón a 10 años del Acuerdo de Asociación Económica. Revista Comercio Exterior (3). http:// revistacomercioexterior.com/articulo.php?id=65\&t=mexico-y-japona-10-anos-del-acuerdode-asociacion-economica. Accessed 8 Aug 2016.

Barfield, Claude. 2011. The TPP: A Model for Twenty-First-Century Trade Agreements? International Economic Outlook (2). Washington, DC: American Institute for Public Policy Research. https://www.aei.org/publication/the-trans-pacificpartnership/. Accessed 30 Dec 2016.

Barfield, Claude, and Philip Levy. 2009. Tales of the South Pacific: President Obama and the Transpacific Partnership. American Enterprise Institute for Public Policy Research 2: 1-9.

Bergsten, C. Fred. 2007. China and Economic Integration in East Asia: Implications for the United States. Policy Briefs in International Economics (PB07-3). Washington, DC: Peterson Institute for International Economics. http://www.iie. com/publications/pb/pb07-3.pdf. Accessed 30 Dec 2016.

Bergsten, C. Fred, and Jeffrey J. Schott. 2010. Submission to the USTR in Support of a Trans-Pacific Partnership Agreement. http://www.iie.com/publications/papers/paper.cfm?ResearchID=1482.

Burlamaqui, Leonardo. 2014. Knowledge Governance: an analytical approach and its policy implications. In Knowledge Governance: reasseserting the public interest, ed. L. Burlamaqui, A.C. Castro, and R. Kattel. London; New York: Anthem Press.

Capaldo, Jeronim, Alex Izurieta, and Jomo Kwame Sundaram. 2016. Trading Down: Unemployment, Inequality and Other Risks of the Trans-Pacific Partnership Agreement. GDAE Working Paper No. 16-01. Medford: Tufts University.

CEE. 2010. Agenda de competitividad: prioridades del sector empresarial 2010-2011. Mexico City: Consejo Coordinador Empresarial.

Chang, Ha Joon. 2002. Kicking away the ladder: development strategy in historical perspective. London: Anthem Press.

Chang, Ha Joon, and Ilene Grabel. 2004. Reclaiming development: an alternative economic policy manual. London: Zed Books.

Contipelli, Ernani, and Simona Picciau. 2015. BRICS Members' Interests and Priorities for Cooperation. The Institutional Status of the BRICS and Pragmatic Cooperation: the case of South America. International Organisations Research Journal 10 (2): 120-128.

de María y Campos, Mauricio. 2016. El TPP, instrumento geopolítico de Estados Unidos frente a China y el Asia emergente: México, ¿a dónde vas? Revista Comercio Exterior 5. http://revistacomercioexterior.com/articulo.php?id=110\&t=eltpp-instrumento-geopolitico-de-estados-unidos-frente-a-china-y-el-asia-emergente. Accessed 8 Aug 2016.

de Rosenzweig Mendialdua, Francisco. 2015. Importancia del Acuerdo de Asociación Transpa-cífico para la política comercial internacional mexicana. Revista Comercio Exterior 3. http://revistacomercioexterior.com/articulo. php?id=60\&t=importancia-del-acuerdo-de-asociacion-transpacifico-para-la-politica-comercial-internacionalmexicana. Accessed 8 Aug 2016.

Deere, Carolyn. 2009. The Implementation Game: The TRIPS Agreement and the Global Politics of Intellectual Property Reform in Developing Countries. Oxford; New York: Oxford University Press.

Dent, Christopher. 2003. Transnational Capital, the State and Foreign Economic Policy: Singapore, South Korea and Taiwan. Review of International Political Economy 10 (2): 246-277.

DiCaprio, Alisa. 2010. US Free Trade agreements and policy flexibility: will new rules hinder industrialisation? Development Policy Review 28 (4): 387-410.

DiCaprio, Alisa, and Kevin P. Gallagher. 2006. The WTO and the shrinking of development space how big is the bite? Journal of World Investment and Trade 7 (5): 781-803.

Dimitrov, Martin K. 2009. Piracy and the State: the politics of intellectual property rights in China. New York: Cambridge University Press.

Drysdale, Peter. 2013. A Breakthrough for Asian Integration? (Editorial). East Asia Forum.

Ernst, Dieter. 2015a. From catching up to forging ahead: China's policies for semiconductors. Honolulu: East-West Center. 
Ernst, Dieter. 2015b. Global strategic patenting and innovation: policy and research implications. Innovation and Economic Growth Series. East West Center Working Papers No. 2.

Falck, Melba E. 2012. Japanese Foreign Direct Investment in Mexico and the Impact of the Global Crisis. Globalization, Competitiveness \& Governability 6 (1): 36-54.

Gallagher, Kevin P. 2007. Measuring the cost of lost policy space at the WTO. Americas Program Policy Brief.

Girard, Bernard. 2012. Does 'strategic patenting'threaten innovation? And what could happen if it did.

Haunss, Sebastian. 2013. Conflicts in the Knowledge Society: the contentious politics of intellectual property. Cambridge: Cambridge University Press.

He, Juan. 2015. The WTO and infant industry promotion in developing countries: perspectives on the Chinese large civil aircraft industry. Oxon; New York: Routledge.

Herreros, Sebastián. 2011. The Trans-Pacific strategic economic partnership agreement: a Latin American perspective. Santiago: Economic Commission for Latin America and the Caribbean (ECLAC/CEPAL).

IMPI. 2016. IMPI en Cifras 2016. Mexico City: Instituto Mexicano de la Propiedad Industrial.

Jung, Heyjie, and Jai S. Mah. 2014. The Role of the government in science and technology education of Korea. Science Technology \& Society 19 (2): 199-227.

Kim, Yee Kyoung, Keun Lee, Walter G. Park, and Kineung Choo. 2012. Appropriate intellectual property protection and economic growth in countries at different levels of development. Research Policy 41 (2): 358-375.

Kolsky Lewis, M. 2011. The Trans-Pacific Partnership: new paradigm or Wolf in Sheep's clothing? Boston College International and Comparative Law Review 34 (1): 27-52.

KPR. 2007. Korea's Research Spending per GDP Ranks 5th in the World. Korea Policy Review 3 (11): 54

Lee, Keun. 2005. Making a technological catch-up: barriers and opportunities. Asian Journal of Technology Innovation 13 (2): $97-131$.

Lee, Keun. 2012. Intellectual property and economic development in the Republic of Korea: an introduction. In The economics of intellectual property in the Republic of Korea, ed. K. Lee. Geneva: World Intellectual Property Organization.

Limaye, Satu. 2011. Want a new map of Asia? Include the United States. Asia Pacific Bulletin.

Liu, Xielin, and Peng Cheng. 2011. Is China's indigenous innovation strategy compatible with globalization? Policy studies 61. Honolulu: East-West Center.

López Aymes, Juan Felipe. 2010. Automobile, information and communication technology and space industries as icons of South Korean Economic Nationalism. Pacific Focus 15 (2): 289-312.

López Aymes, Juan Felipe, and Alejandra Salas-Porras. 2012. Korean companies in Mexico: business practices and national identity. Journal of Asia-Pacific Business 13 (4): 349-374.

Olwan, Rami M. 2013. Intellectual property and development: theory and practice. Berlin; New York: Springer.

Ordover, Janusz A. 1991. A patent system for both diffusion and exclusion. Journal of Economic Perspectives 5 (1): 43-60.

Park, Nowook. 2012. Intellectual property promotion policies and their impact in Korea. In The economics of intellectual property in the Republic of Korea, ed. K. Lee. Geneva: World Intellectual Property Organization.

Petri, Peter A., Michael G. Plummer, and Fan Zhai. 2011. The Trans Pacific Partnership and Asia Pacific Integration: a quantitative assessment, economic series. Working Paper No. 119. Honolulu: East West Center.

Rochon, Nicolas. 2013. In the dark, the Trans-Pacific Partnership advances to the next round of negotiation. The International.

Sakai, Tanaka. 2011. Why the new "emphasis on Asia" in U.S. Policy? The Asia-Pacific Journal 9(49).

Schneider, Patricia Higino. 2005. International trade, economic growth and intellectual property rights: a panel data study of developed and developing countries. Journal of Development Economics 78 (2): 529-547.

Shadlen, Kenneth C. 2005. Exchanging development for market access? Deep integration and industrial policy under multilateral and regional-bilateral trade agreements. Review of International Political Economy 12 (5): 750-775.

Shadlen, Kenneth C. 2012. The Mexican exception: patents and innovation policy in a non-conformist and reluctant middle income country. The European Journal of Development Research 24 (2): 300-318.

Solis, Mireya. 2011. Last Train for Asia-Pacific Integration? U.S. Objectives in the TPP Negotiations. Working Paper No. 201102. Tokyo: Waseda University Organization for Japan-US Studies.

Stiglitz, Joseph E. 2006. Making globalization work. New York: W. W. Norton \& Company.

Stiglitz, Joseph E, and Adam S. Hersh. 2015. The Trans-Pacific Free-Trade Charade. Project Syndicate. https://www.projectsyndicate.org/commentary/trans-pacific-partnership-charade-by-joseph-e--stiglitz-and-adam-s--hersh. Accessed 15 June 2016

Yoon, Ji Woong. 2014. Evolution of science and technology policy in Korea. The Korean Journal of Policy Studies 29 (1): $147-172$. 